\title{
EXPONENTIAL CONVEXITY, POSITIVE SEMI-DEFINITE MATRICES AND FUNDAMENTAL INEQUALITIES
}

\author{
M. Anwar, J. JakŠEtić, J. PeČARIĆ And AtiQ UR Rehman
}

Abstract. The first two chapters of the classical book [6] on inequalities are devoted to fundamental inequalities and positive definiteness. In this paper we obtain results which give connection between fundamental inequalities and positive definiteness using the notion of exponential convexity.

Mathematics subject classification (2010): Primary 26A51; Secondary 26A46, 26A48.

Keywords and phrases: Jensen, Jensen-Steffensen, Steffensen, Aczél, Mercer, Levinson inequalities, inequalities for power sums, exponentially convex functions, linear functionals, positive semi-definite matrices.

\section{REFERENCES}

[1] N.I.AkHIEZer, The Classical Moment Problem and Some Related Questions in Analysis, Oliver and Boyd, Edinburgh, 1965.

[2] M. ANWAR AND J. PeČARIĆ, On logarithmic convexity for differences of power means and related results, Math. Inequal. Appl., 12, 1 (2009), 81-90.

[3] M. AnWAR AND J. PeČARIĆ, On logarithmic convexity for Ky-Fan inequality, J. Inequal. and Appl. Article ID 870950, 4 pages Volume (2008).

[4] M. AnWAR And J. PeČARIĆ, New Means of Cauchy's Type, Journal of Inequalities and Applications, Article ID 163202, 10 pages Volume (2008).

[5] M. Anwar And J. PeČArić, Cauchy's Means of Levinson Type, JIPAM, 9, 4 (2008), Article 120.

[6] E. Beckenbach and R. Bellman, Inequalities, Springer-Verlag, Berlin, 1961.

[7] S. N. Bernstein, Sur les fonctions absolument monotones, Acta Math., 52 (1929), 1-66.

[8] W. S. Cheung, A. Matković, And J. PeČArić, A variant of Jessen Inequality and Genralized Means, J. Inequal. Pure \& Appi. Math., 7, 1 (2006), Article 10.

[9] P. J. DAVIS, Interpolation and approximation, Dover, New York, 1975.

[10] J. P. GRAM, Über die Entwicklung realen Funktionen in Reihen mittelst der Methode der kleinsten Quadrate, J. Reine Angewendte Math., 94 (1883), 41-73.

[11] G. H. Hardy, J. E. Littlewood, G. Pólya, Inequalities, Cambridge University Press, Cambridge, 1978.

[12] I. I. Hirschman And D. V. Widder, The Convolution-transform, Princeton Univ. Press. 1955.

[13] J. JAKŠETIĆ AND J. E. PeČARIĆ, Means involving functionals and n-convex functions, Math. Inequal. Appl., to appear (2009).

[14] J. JAKŠETIĆ AND J. E. PeČARIĆ, Steffensen's means, J. Math. Inequal., 2 (2008), 487-498.

[15] J. JAKŠEtić AND J. E. PeČARIĆ, Generalized Steffensen means, Bull. Iran. Math. Soc., to appear (2009).

[16] H. J. Rossberg, B. Jesiak, G. Siegel, Analytic Methods of Probability Theory, Akademie-Verlag, Berlin, 1985.

[17] S. KuREPA, Konačno dimenzionnalni vektorski prostori i primjene, Tehničke Knjige, Zagreb, 1990.

[18] N. Levinson, Generalization of an Inequality of Ky Fan, J. Math. Anal. Appl., 8 (1964), 133-134.

[19] D. S. Mitrinović, Analytic Inequalities, Springer-Verlag, Berlin, 1970.

[20] D. S. Mitrinović, J. E. PeČArić, On Some Inequalities for Monotone Functions, Bolletino U. M. I., 7, 5-B (1991), 407-416. 
[21] D. S. Mitrinović, J. PeČArIĆ AND A. M. Fink, Classical and new inequalities in analysis, Kluwer Academic Publishers, The Netherlands, 1993.

[22] J. Pečarić, F. Proschan and Y. C. Tong, Convex functions, Partial Orderings and Statistical Applications, Academic Press, New York, 1992.

[23] J. E. PEČARIĆ, Inverse of Jensen-Steffensen's ineqauality, Glasnik Matematički, 16, 36 (1981), 229233.

[24] J. PeČARIĆ, On an inequality of N. Levinson, Univ. Beograd, Publ. Elektrotehnin Fak. Ser. Mat. Fiz. Nos., 678-715 (1980), 71-74.

[25] J. PeČARIĆ, An inequality for 3-Convex Functions, J. Math. Anal. Appl., 19 (1982), 213-218.

[26] J. PeČARIĆ AND ATIQ UR Rehman, On logarithmic convexity for Power sums and related results, J. Inequal. and Appl. Article ID 389410, 9 pages Volume (2008).

[27] J. PeČARIĆ AND ATIQ UR Rehman, On logarithmic convexity for Power sums and related results II, J. Inequal. and Appl. Article ID 305623, 12 pages Volume (2008).

[28] W. Sierpins KI, Sur les fonctions convexes mesurables, Fund. Math. (Warsaw), 1 (1920), 125-129. 